\title{
Efficient Planning of Electrical Distribution System for Consumers in Sarawak, Malaysia
}

\author{
Ibrahim S.H. ${ }^{a^{*}}$, Baharun A. ${ }^{a}$, Nawi M.N.M ${ }^{b}$, Chai C.J. ${ }^{a}$ \\ ${ }^{a}$ Department of Civil Engineering, Faculty of Engineering, Universiti Malaysia Sarawak, Kota Samarahan, Sarawak, Malaysia \\ ${ }^{b}$ School of Technology Management and Logistic, Universiti Utara Malaysia, 06010 Sintok, Kedah, Malaysia
}

*Corresponding author: ihalipah@feng.unimas.my

Article history

Received: 19 June 2014

Received in revised form:

25 September 2014

Accepted: 1 December 2014

\section{Graphical abstract}

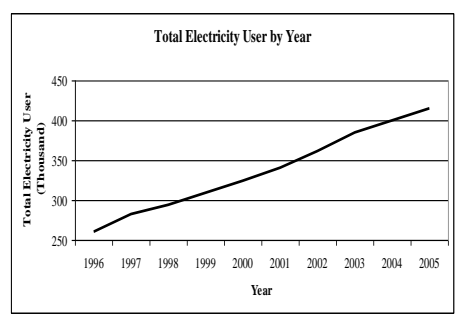

\section{Abstract}

This study presents a method to determine power consumption pattern for several types of consumers in Sarawak, Malaysia. The power consumption data for consumers has been recorded using EDMI Mk.6 Genius polyphase electronic (E3) meters installed at their premises. The multistage cluster sampling is used to design the sample size to determine the sufficient amount of meters required. The data obtained from the meters has been analysed to obtain the pattern of power consumption for different types of consumers. This power consumption pattern has been applied to determine load factor, diversity factor for the calculation of After Diversity Maximum Demand (ADMD). ADMD is also used to determine the optimal amount of load, distribution transformer size and $11 \mathrm{kV}$ cable size. Temperature sensitivity analysis related to the demand has been investigated as well. It is found that power consumption pattern model is beneficial in finding the total electrical load, distribution transformer size and $11 \mathrm{kV}$ cable size needed by the consumers. Thus through this study the load characteristics had been determined to support utility operation and planning efficiently.

Keywords: After Diversity Maximum Demand (ADMD), diversity factor, load factor, maximum demand, power consumption pattern.

(C) 2012 Penerbit UTM Press. All rights reserved.

\subsection{INTRODUCTION}

Rapid growth of population and depletion of fossil fuel has generated subsequent increment in demand for electrical power. Sarawak Energy Berhad (SEB) needs to raise its total power generating capacity to 7,000 MW by 2025 to meet the anticipated demand from new energy-intensive industries in the Sarawak and the load demand is expected to grow to $2,550 \mathrm{MW}$ by 2020 and could potentially reach $3,700 \mathrm{MW}$ by 2025 .Thus, power consumption patterns play an important role in improving system planning, operation and maintenance efficiency .

The total number of power consumer in Sarawak has increased from 260,214 in 1996 to 414,767 in 2005 . The growth rate of electricity consumers within 10 years is $59.39 \%$. Total electricity sold is $1.94 \mathrm{TWh}$ in 1996 and increased to $3.94 \mathrm{TWh}$ in 2005. The growth rate of total electricity sold within 10 years is $103.09 \%$. Due to the dramatic increment in electricity consumption as shown in Figure 1 and Figure 2, the power consumption pattern, consumer behaviour and electrical load characteristic become critical issues to be investigated. Therefore, efficient systems in planning, operation and maintenance need to be designed to meet the yearly increment of peak demand

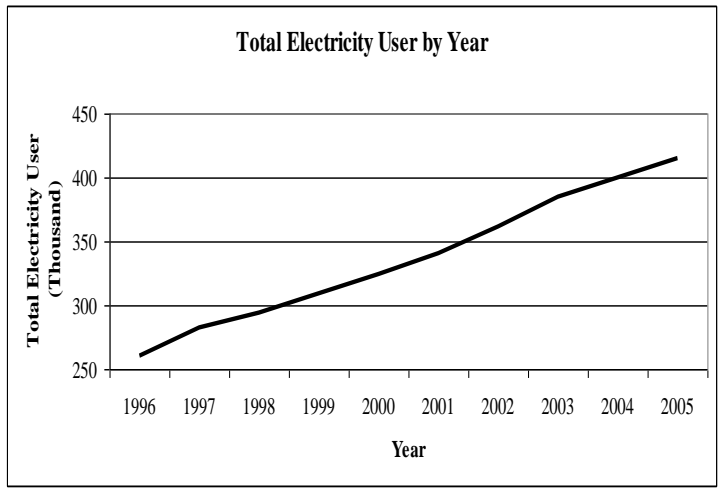

Fig. 1 Total electricity consumer in Sarawak from year 1996 to 2005 




Fig. 2 Total unit sold (TWh) by Syarikat SESCO Berhad from year 1996 to 2005 [4]

This study focused on power consumption pattern, load factor, diversity factor, After Diversity Maximum Demand (ADMD) and analysis on temperature sensitivity related to the demand for selected types of consumers using multistage cluster sampling theory [ ] as shown in Table 1.

Table 1 Type of consumers

\begin{tabular}{|l|c|}
\hline Types of Houses & $\begin{array}{c}\text { Types of Consumers } \\
\text { by Tariff Class }\end{array}$ \\
\hline Detached House & Domestic \\
\hline Semi Detached House & Domestic \\
\hline Terrace & Domestic \\
\hline Residential Unit Floor & Domestic \\
\hline Commercial Unit Floor & Commercial \\
\hline
\end{tabular}

Measured data to obtain the electricity consumption pattern for various residential and commercial consumers had been analysed to derive three (3) key characteristic parameters; the load factor, load diversity, and After Diversity Maximum Demand (ADMD). By using the load factor data for each type of consumers, the possible mix of residential and commercial consumers that resulted in an optimal aggregate load factor could be determined. The distribution of transformer size and $11 \mathrm{kV}$ cable size can be determined accurately from the electrical load which based on calculation of power consumption data. This could prevent power failure due to improper planning. Supplier can provide better marketing strategies and forecast the electrical load accurately if the power consumption pattern known at early stage Different researchers have different methods to embrace the power consumption pattern for estimating diversity and maximum demand, finding the electrical load characteristics of the consumer and to perform temperature sensitivity analysis of consumer power consumption, designing a proper tariff structure for the utility by considering the power consumption pattern of consumers, determine the demand characteristics and comparing the power consumption pattern for the different types of consumers and analysing the differences in their consumption behaviour.

For this study, three (3) factors had been chosen to determine the power consumption pattern as followed:
A.Consumer

Different type of consumers will have different type, number and size of electrical appliance based on their needs.

B. Time

Different types of consumers will be using different amount of electricity at various time. The usage of electricity is based on daily activity.

C. Weather

Weather conditions will influence the power consumption pattern. During the hot season, consumer will be using air conditioning unit or fan more frequently.

\subsection{SAMPLING DESIGN}

This study focused on five (5) types of consumers (detached house, semi-detached house, terrace house, residential unit floor and commercial unit floor). Sampling design has been implemented to derive the power consumption pattern for various types of consumers. It is necessary to apply the sampling theory to select the proper size of consumers in order to reduce the analytical lost of the electrical load data.

The sampling method is applied based on the amount of different types of consumers within the selected area. The population proportion $\mathrm{p}$ and size of the population $\mathrm{N}$ of total unit for each type of consumer is needed to design the proper sample size,. The minimum sample size, $\mathrm{S}$ with $90 \%$ confidence level [11] for each type of the consumers is determined by using Equations (1) and (2)

$$
\begin{aligned}
& S=\frac{S_{0}}{1+\frac{S_{0}-1}{N}} \\
& S_{0}=\frac{z^{2} p q}{e^{2}}
\end{aligned}
$$

Where,

$\begin{array}{lll}\mathrm{S} & \text { Sample size } \\ \mathrm{N} & \begin{array}{l}\text { Size of the population } \\ \mathrm{z}\end{array} & \begin{array}{l}\text { Standard score corresponding to a given confidence } \\ \end{array} \\ \mathrm{p} & \text { level } & \text { Population proportion } \\ \mathrm{q} & & (1-\mathrm{p}) \\ \mathrm{e} & & \text { Proportion of sampling error }\end{array}$

The EDMI Mk.6 Genius polyphase electronic (E3) meters have been installed in consumer premises to determine each type consumer power consumption pattern, consumer behaviour and load characteristics based on sample size.

Meters had been installed at the selected consumer premises to measure and record the power consumption within every 15 minutes over 2 months period. The daily power consumption pattern for each type of the consumer can be derived based on the power consumption data collected from the meters. This power consumption pattern is used to determine several other factors such as load factor and diversity factor. Average demand and maximum demand is needed to determine the load factor and the load factor for each type of the consumers will be determined by using Equation 3 


$$
\text { Load Factor }=\frac{\text { Average } 15-\min \mathrm{kW} \text { demand }}{\text { Maximum } 15-\min \mathrm{kW} \text { demand }}
$$

The maximum non-coincident demand of a group consumers and maximum diversified demand of the group is required to determine the diversity factor and the diversity factor for each type of the consumers has been determined by using Equation 4

$$
\text { Diversity Factor }=\frac{\text { Max noncoincident demand }}{\text { Max diversified demand }}
$$

When the diversity factor for different types of consumers has been determined, the value of ADMD could be calculated.

The After Diversity Maximum Demand (ADMD) for each type of the consumers has been determined by using Equation 5 [ ]

$\operatorname{ADMD}(\mathrm{N})=\frac{\text { Max recorded load for } \mathrm{N} \text { customers }}{\mathrm{N}} \mathrm{kVA}(5)$

Where $\mathrm{N}$ is the number of consumers connected.

After $\operatorname{ADMD}(\mathrm{N})$ is determined, $\mathrm{ADMD}(\mathrm{inf})$ can be determined by using Equation 6 [15].

$$
\operatorname{ADMD}(\mathrm{inf})=\frac{\mathrm{ADMD}_{(\mathrm{N})}}{\mathrm{DF}_{(\mathrm{N})}} \mathrm{kVA}
$$

$\operatorname{ADMD}(\mathrm{inf})$ is a value that required to assign each unit of different types of consumers and to determine the size of the distribution transformer and $11 \mathrm{kV}$ cable. The distribution transformer size is selected when the loading is less than $80 \%$ of the nameplate rating.

$11 \mathrm{kV}$ cable size is selected based on capacity. Due to the deterministic N-1 criteria, only half of the cable capacity is used. As long as total load is less than $50 \%$ of the capacity of the $11 \mathrm{kV}$ cable that has been selected, the $11 \mathrm{kV}$ cable capacity can be calculated by using Equation 7

$11 \mathrm{kV}$ Cable Capacity $=$ Current Rating $\mathrm{x} 11 \mathrm{kV}$ x

To investigate the effect of the temperature changes on the consumer demand, the sensitivity analysis of the temperature has been compared to the power consumption for each types of consumers (detached house,semi-detached house,terrace house, residential unit floor and commercial unit floor). The time when the maximum demand occurs is used to determine the relationship between demand and temperature sensitivity. By using regression method, the relationship between demand and temperature can be determined.

Improving overall load factor can reduce unit cost of the kilowatt-hour $(\mathrm{kWh})$ and increase the efficiency of equipment system. Overall load factor can be improved through the combination of specific amount of commercial unit floor consumer and the domestic consumer for new area development.

\subsection{RESEARCH METHODOLOGY}

A power consumption pattern model has been created in order to assist the user to calculate total electrical load, distribution transformer size and $11 \mathrm{kV}$ cable size needed based on total units of commercial unit floor, residential unit floor and different types of houses needed. Methodology used for this study shown in Figure 3.

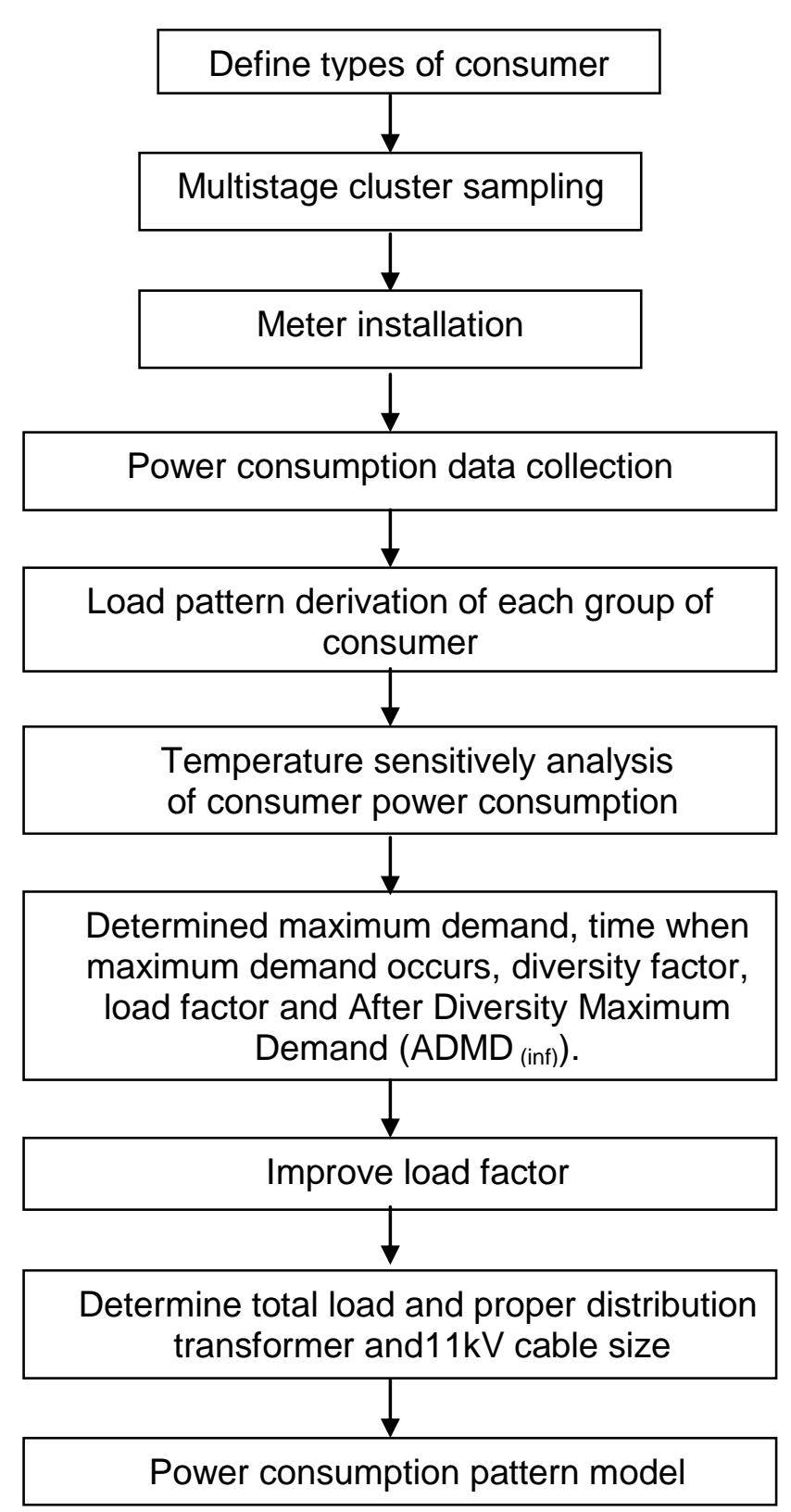

Figure 3 Study procedures on power consumption pattern

It is essential to use the sampling theory to select a proper size of consumer for meter installation. By using Equation 1 and 2, the sample sizes for several types of consumers have been calculated as shown in Table 2 .

Table 2 Sample size

\begin{tabular}{|l|c|}
\hline Type of Consumer & Sample Size \\
\hline Detached House & 34 \\
\hline Semi-Detached House & 47 \\
\hline Terrace House & 68 \\
\hline Residential Unit Floor & 41 \\
\hline Commercial Unit Floor & 36 \\
\hline
\end{tabular}




\subsection{COMPARISON OF POWER CONSUMPTION PATTERN FOR SEVERAL TYPES OF CONSUMERS}

Power consumption pattern is influenced by consumer behaviour and time factor as shown in Figure 4. The data shows that demand for domestic consumers like detached house, semi-detached house, terrace house and residential unit floor having similar characteristics; the demand is higher during nighttime compare to daytime. However, the maximum demand will be different due to the consumers' behaviour. Demand for the commercial unit floor is higher during daytime and lower during nighttime. The characteristic of power consumption pattern for domestic consumer is opposite to the commercial unit floor consumer. The summary of maximum demand and the time when maximum demand occur for several types of consumer is shown in Table 3. Table 3 shows maximum demand of the commercial unit floor consumer is the highest among the other consumers, followed by detached house consumer, semi-detached house consumer, terrace house consumer and residential unit floor.

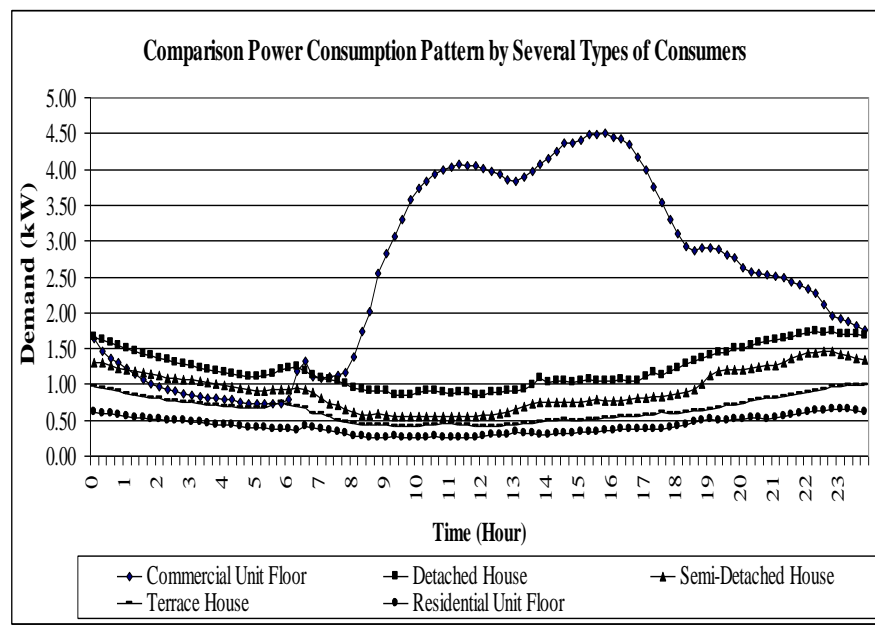

Figure 4 Comparison power consumption pattern for various types of consumers

Table 3 Maximum demand and time when the maximum demand occurs for various types of consumer

\begin{tabular}{|l|c|c|}
\hline Consumer & Time & $\begin{array}{c}\text { Maximum Demand } \\
(\mathbf{k W})\end{array}$ \\
\hline Commercial Unit Floor & 15.45 & 4.51 \\
\hline Detached House & 22.15 & 1.74 \\
\hline Semi-Detached House & 22.30 & 1.46 \\
\hline Terrace House & 23.45 & 0.98 \\
\hline Residential Unit Floor & 23.15 & 0.65 \\
\hline
\end{tabular}

15.0 COMPARISON OF LOAD FACTOR FOR SEVERAL TYPES OF CONSUMERS

The efficiency of using system equipment can be determined by using load factor. The electrical load reached the peak level on the system when the average demand approaches the maximum demand during daytime. Table 4 shows detached house consumer has the highest load factor, followed by terrace house consumer, residential unit floor consumer, semi-detached house consumer and commercial unit floor consumer. This shows that detached house consumer has the highest usage of the system equipment and lowest loss of electricity supply by the supplier. Commercial unit floor consumer has the lowest load factor.

Table 4 Load factor for various types of consumer

\begin{tabular}{|l|c|}
\hline Consumer & Load Factor (\%) \\
\hline Detached House & 70.01 \\
\hline Terrace House & 65.36 \\
\hline Residential Unit Floor & 63.74 \\
\hline Semi-Detached House & 63.51 \\
\hline Commercial Unit Floor & 55.96 \\
\hline
\end{tabular}

Detached house consumer has the lowest energy waste compare to commercial unit floor consumer. The commercial unit floor consumer has the lowest load factor due to higher demand during daytime. During nighttime, most of the shophouses are vacant and most of the electrical appliances are switched off. This causes a dramatic drop in demand for electricity for this type of consumer. Therefore, when the average demand is compared to maximum demand, the load factor will be lower. While for the domestic consumer, during daytime, most houses are vacant, but electrical appliance such as refrigerator is still switched on. So the difference in demand for domestic consumer between daytime and nighttime is not as obvious as the commercial unit floor consumer.

\subsection{COMPARISON OF DIVERSITY FACTOR AND AFTER DIVERSITY MAXIMUM DEMAND (ADMD) FOR SEVERAL TYPES OF CONSUMERS}

Diversity factor allows the utilities to meet the demand. The consumers have their own behavior and characteristic; therefore the maximum demand occurs at different point of time and affects the diversity factor.

The value of ADMD is used to determine the electrical load needed for each type of consumers. ADMD for every type of consumers were different due to the different types of consumers' behaviour. Table 5 shows the summary of the diversity factor and ADMD of several types of consumers.

Table 5 Diversity factor and After Diversity Maximum Demand (ADMD) for various types of consumers

\begin{tabular}{|l|c|c|}
\hline Type of Consumer & Diversity Factor & $\begin{array}{c}\text { ADMD(inf) } \\
(\mathbf{k V A})\end{array}$ \\
\hline Detached House & 1.22 & 1.64 \\
\hline Semi-Detached House & 1.20 & 1.40 \\
\hline Terrace House & 1.29 & 0.85 \\
\hline Residential Unit Floor & 1.29 & 0.60 \\
\hline Commercial Unit Floor & 1.11 & 4.66 \\
\hline
\end{tabular}

Commercial unit floor consumer has the highest value of ADMD compared to other types of consumer. The highest value of ADMD shows the highest demand is required by commercial unit floor consumer to support their daily activity. From other point of view, commercial unit floor consumer has the lowest diversity factor due to the constant demand and individual maximum demand occurs during daytime.

From the data collected, its shows that domestic consumers like detached house consumer, semi-detached house consumer, terrace house consumer and residential unit floor consumer has the ADMD lower than commercial unit floor consumer. Residential unit floor consumer has the lowest value of ADMD. Terrace house consumer and residential unit floor consumer have the highest diversity factor. The highest diversity factor is due to 
the maximum individual demand which occur at different times. The highest diversity factor means that individual maximum demand will be widely spread at different time. Result shows that domestic consumers have diversity factor higher than commercial unit floor consumer. This shows cost efficiency of the system for domestic consumers is higher than the commercial unit floor consumer.

\subsection{TEMPERATURE SENSITIVITY ANALYSIS OF CONSUMER POWER CONSUMPTION}

Figure 5 to Figure 9 illustrate the temperature analysis for several types of consumers. By using regression method, the relationship between demand and temperature can be represented by an equation where demand is represented as kilowatt $(\mathrm{kW})$ and temperature $\left({ }^{\circ} \mathrm{C}\right)$ is represented as T. Figure 5 to Figure 9 show that the demand are proportional increased with temperature, which proves that temperature influences the demand. Equation 8 to Equation 12 indicate that temperature has a great effect on the demand. When the temperature increased, the demand will be increased proportionally.

Equation 8 shows the relationship between demand and temperature for detached house consumer.

$$
\mathrm{kW}=0.0011 \mathrm{~T}^{2}+0.0179 \mathrm{~T}+1.5092
$$

With R-squared value 0.9290

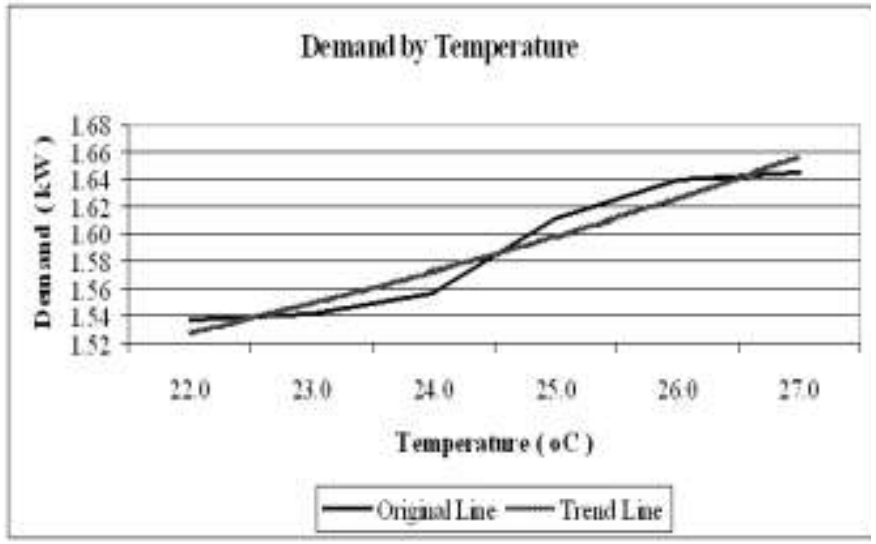

Fig. 5 Temperature analysis for detached house consumer

Equation 9 shows the relationship between demand and temperature for semi-detached house consumer.

$$
\mathrm{kW}=0.0002 \mathrm{~T}^{2}+0.0181 \mathrm{~T}+1.2744
$$

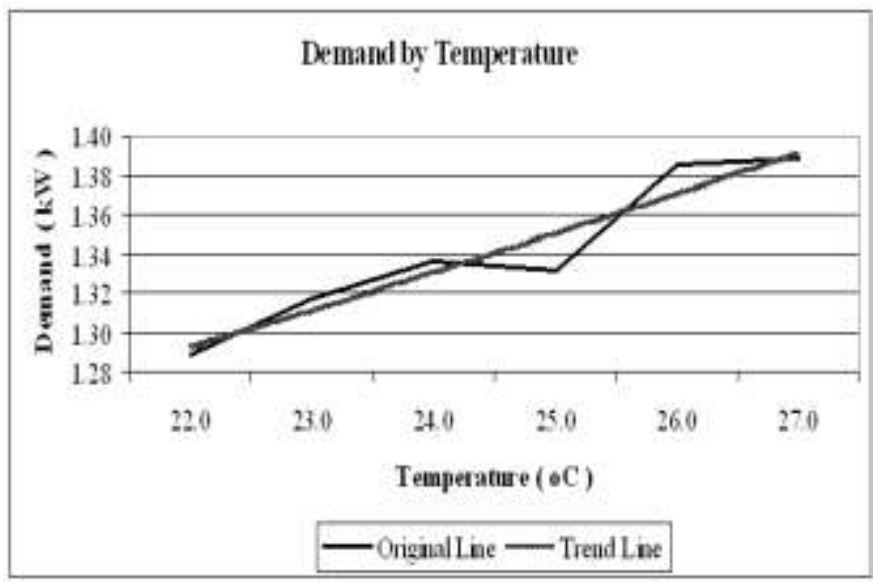

Fig. 6 Temperature analysis for semi-detached house consumer

Equation 10 shows the relationship between demand and temperature for terrace house consumer.

$$
\mathrm{kW}=0.0002 \mathrm{~T}^{2}+0.0191 \mathrm{~T}+0.8023
$$

With R-squared value 0.9724

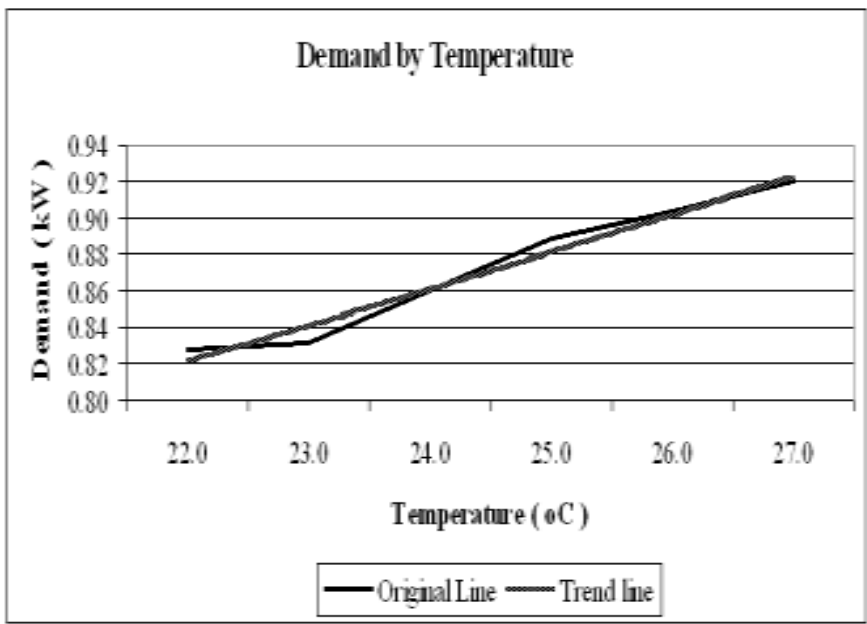

Fig. 7 Temperature analysis for terrace house consumer

Equation 11 shows the relationship between demand and temperature for residential unit floor consumer.

$$
\mathrm{kW}=0.0006 \mathrm{~T}^{2}+0.0145 \mathrm{~T}+0.4893
$$




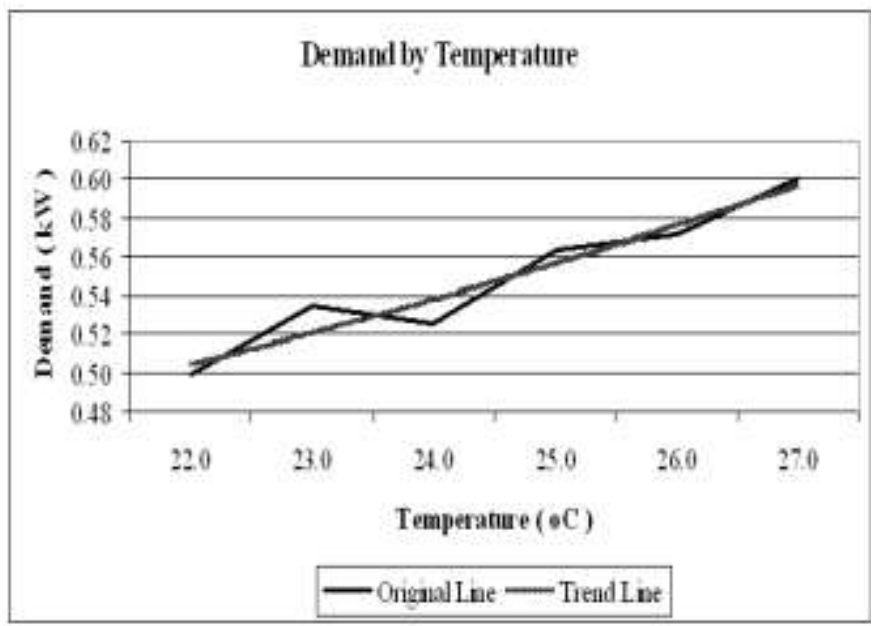

Fig. 8 Temperature analysis for residential unit floor consumer

Equation 12 shows the relationship between demand and temperature for commercial unit floor consumer.

$\mathrm{kW}=0.0023 \mathrm{~T}^{2}+0.0368 \mathrm{~T}+3.5492$

With R-squared value $=0.9657$

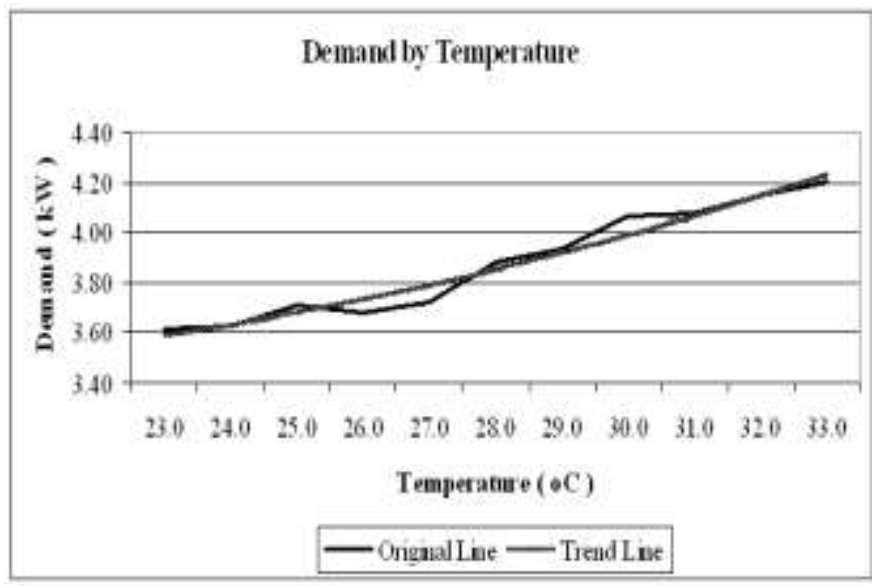

Fig. 9 Temperature analysis for commercial unit floor consumer.

\subsection{IMPROVEMENT OF OVERALL LOAD FACTOR}

Power consumption pattern for commercial unit floor consumer has opposite characteristic compared to the domestic consumer where the demand for commercial unit floor consumer is higher during daytime and vice versa. However, load factor could be improved by combining these two types of consumers. Figure 10 shows the changes of the load factor pattern when commercial unit floor consumer and domestic consumer are combined for a total 100 test samples.

Power consumption pattern for commercial unit floor consumer has opposite characteristic compared to the domestic consumer where the demand for commercial unit floor consumer is higher during daytime and vice versa. However, load factor could be improved by combining these two types of consumers. Figure 10 shows the changes of the load factor pattern when commercial unit floor consumer and domestic consumer are combined for a total 100 test samples.

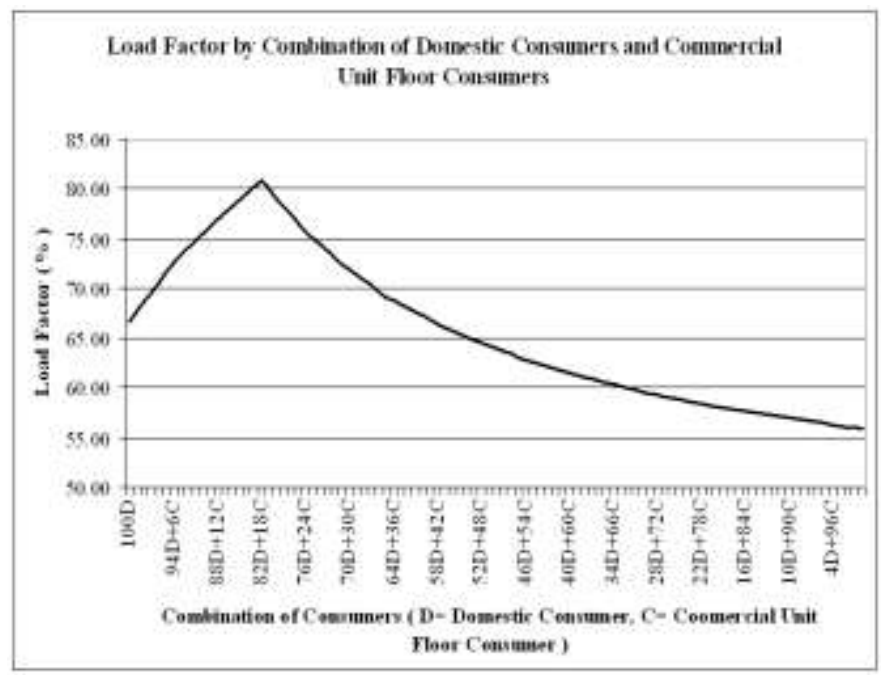

Figure 10 Improving load factor

Initially the load factor for 100 units of domestic consumers is $66.64 \%$ and the 100 units of commercial unit floor consumers are $55.96 \%$. Figure 10 shows that the load factor reaches the highest value of $80.83 \%$ when 18 units of commercial unit floor consumers are added to 82 units of domestic consumers. For a developing area, the combination of $18 \%$ of commercial unit floor consumers to $82 \%$ of domestic consumers will greatly improve the overall load factor. By using the combination methods of these two types of consumers which have opposite characteristics of power consumption pattern, this shows that load factor could be improved significantly.

\subsection{POWER CONSUMPTION PATTERN MODEL}

Power consumption pattern model has been created in this study as shown in Figure 11 using MATLAB source code. This model had been developed in assisting the user to calculate total electrical load, distribution transformer size and $11 \mathrm{kV}$ cable size. Using this model to calculate the total electrical load for 150 units of detached house, 300 units of semi detached house, 500 units of terrace house, 200 units of residential unit floor and 400 units of commercial unit floor are 3.08MVA. By using this power consumption pattern model, four distribution transformer size of $1000 \mathrm{kVA}$ is suggested by the model due to the total electrical load and $185 \mathrm{~mm} 2 \mathrm{AL} 3 \mathrm{C}$ XLPE cable is selected in this case. The capacity of this type of $11 \mathrm{kV}$ cable will be around 6.38MVA. Since a deterministic $(\mathrm{N}-1)$ criterion has taken into consideration, only half of the actual capacity of $11 \mathrm{kV}$ cable is used. Therefore, $185 \mathrm{~mm} 2$ AL 3C XLPE cable has been selected which can support up to 3.19MVA when the actual load needed is 3.08MVA. 


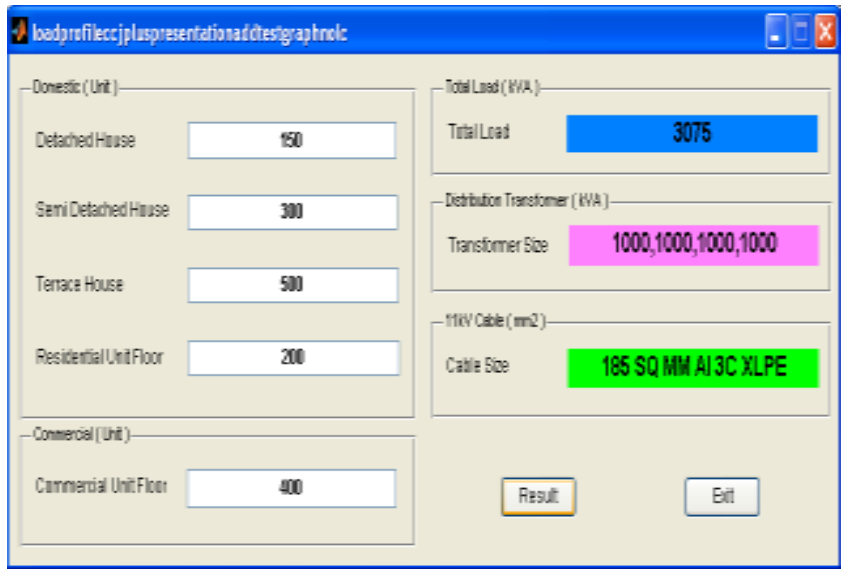

Figure 11 Power consumption mode

\subsection{CONCLUSION}

Determining consumer load characteristics is an important step to improve system operation, maintenance and planning efficiency. This study had developed Power consumption pattern model that proven could perform well in calculating the total electrical load, distribution transformer size and cable size needed based on the type of consumers. Thus through this study the load characteristics can be determined to support utility operation and planning effectively.

\section{Acknowledgement}

The author gratefully acknowledges the help from Syarikat SESCO Berhad to provide valuable information, technical support and budget for this project.
References

[1] Sarawak Energy needs to raise generating capacity to 7,000 MW http://www.thestar.com.my/Business/Business-News/ Monday May 12, 2014 (retrieved on 7 September, 2014)

[2] Hwang, J.C. and Huang, C.W. 2004. The Application of Load Characteristic Services System for Improved Customer Services in Taipower. IEEE.

[3] Nizar, A.H., Dong, Z.Y., Jalaluddin, M. and Raffles, M.J. 2006. Load Profiling Method in Detecting non-Technical Loss Activities in a Power Utility. IEEE Transactions on Power Delivery. 82-87.

[4] Ngu, S.S., Kho, L.C., Annie, J., Chai, C.J. and Leslie Chai, K.P. 2007. Power Consumption Pattern of Consumer in Kuching Sarawak. Proceedings of the 1st Engineering Conference: Energy and Environment (ENCON2007). Kuching.

[5] Chang, F.C., Rong, C.L. and Chan. 2002. Distribution Transformer Load Modelling Using Load Research Data. IEEE Transactions on Power Delivery. 17(2).

[6] Gerbec, D., Gasperic, S., Smon, I. \& Gubina, F. 2002. An Approach to Consumers Daily Load Profile Determination. IEEE.

[7] Chen, C.S., Kang, M.S., Hwang, J.C. \& Huang, C.W. 2001. Temperature Effect to Distribution System Load Profiles and Feeder Losses. IEEE Transactions on Power System. 16(4).

[8] Sargent AI., Broadwater R.P., Thompson J.C. and Nazarko J. 1993. Estimation of diversity and kWHR-to-peak-kW factors from load research data. IEEE Transactions on Power System. 1450-1456.

[9] Chen, C.S., Hwang, J.C., Tzeng, Y.M., Huang, C.W. \& Cho, M.Y. 1995. Determination of consumer load characteristics by load survey system at Taipower. IEEE Transactions on Power Delivery. 1430-1436.

[10] Chen, C.S., Hwang, J.C. \& Huang, C.W. 1997. Application of load survey systems to proper tariff design. IEEE Transactions on Power System. Volume 12(4):1746-1751

[11] Yu, I.H., Lee, J.K., Ko, J.M. \& Kim, S.I. 2005. Computer and Information Science. Fourth Annual ACIS International Conference. 164-168.

[12] Johnson, R. and Kuby, P. 2005. Just the Essentials of Elementary Statistics. United States of America: Duxbury - Thompson Learning.

[13] Luck, D.J., Taylor, W.G. \& Robin. 1987. Marketing Research Eaglewood. Prentice Hall.

[14] Pasini, A.J. 1992. Guide to Electrical Power Distribution System. Englewood Cliffs. New Jersey: Prentice Hall.

[15] Kersting, W.H. 2002. Distribution System Modeling and Analysis. United States of America: CRC Press 